\title{
Value elements of industrial maintenance: Verifying the views of the customer and service provider
}

\section{Maaren Ali-Marttila*}

School of Industrial Engineering and Management Lappeenranta University of Technology

P.O Box 20

FIN-53851 Lappeenranta, Finland

E-mail: maaren.ali-marttila@lut.fi

*Corresponding author

\section{Leena Tynninen}

School of Industrial Engineering and Management Lappeenranta University of Technology

P.O Box 20

FIN-53851 Lappeenranta, Finland

E-mail: leena.tynninen@lut.fi

\section{Salla Marttonen}

School of Industrial Engineering and Management Lappeenranta University of Technology P.O Box 20

FIN-53851 Lappeenranta, Finland

E-mail: salla.marttonen@lut.fi

\section{Timo Kärri}

School of Industrial Engineering and Management Lappeenranta University of Technology

P.O Box 20

FIN-53851 Lappeenranta, Finland

E-mail: timo.karri@lut.fi

\begin{abstract}
To maximize the total value in a maintenance business relationship it is important to know what the partner values. The value of industrial maintenance service can be considered to consist of value elements, and the perceived total value for the customer and service provider is the sum of these value elements. The specific objectives of this paper are to verify the most important value elements for the maintenance service customer and provider and also to recognize where the value elements differ, by using the non-parametric tests Wilcoxon and Mann-Whitney U. The data has been collected by an online survey sent to 345 maintenance service professionals in Finland. In the survey, four different types of value elements were considered: the customer's high critical and
\end{abstract}




\section{Author}

low critical items and the service provider's core and support service. The most valued elements by the respondents were reliability, safety at work, environmental safety, and operator knowledge.

Keywords: value, value element, maintenance, maintenance services, customer, service provider, supplier, value creation, value profile, collaboration, win-win, survey, MannWhitney U, Wilcoxon

Biographical notes: Maaren Ali-Marttila is a Doctoral Student at the School of Industrial Engineering and Management, Lappeenranta University of Technology, Finland. She is currently involved in the research project MaiSeMa (Industrial Maintenance Services in a Renewing Business Network: Identify, Model and Manage Value), and her research focuses on the value and value elements of industrial maintenance services and enhancing co-operation in company networks.

Leena Tynninen is a University Lecturer at the School of Industrial Engineering and Management, Lappeenranta University of Technology, Finland. She teaches cost management and her research interests include customer accounting, customer profitability and activity-based costing/management.

Salla Marttonen is a Post-Doctoral Researcher and Project Manager at the School of Industrial Engineering and Management, Lappeenranta University of Technology, Finland. She received her D.Sc. (Tech.) in 2013; her dissertation addressed flexible asset management in industrial maintenance. She works in the research team of capital, capacity and cost management $(\mathrm{C} 3 \mathrm{M})$. Her research interests include value, costs and profitability of maintenance and asset management in companies and company networks.

Timo Kärri is a Professor at the School of Industrial Engineering and Management, Lappeenranta University of Technology, Finland. He received his D.Sc. (Tech.) in Industrial Management in 2007. His dissertation considered timing of capacity changes in capital intensive industries and his current research interests include capital, capacity, and cost management.

Acknowledgements: The authors would like to thank the anonymous reviewers for constructive comments and suggestions. The authors are also grateful for the Finnish Funding Agency for Innovation, Tekes for funding the research.

\section{Introduction}

Value, adding value and shared value in services have been a major focus in service literature and are often highlighted to the customers and providers. However, the definitions of value are vague. Customer value is generally defined as the tradeoff between the give (sacrifices) and get (benefits) components (Zeithaml, 1988). The benefits can include for example quality, whereas price can be seen as a sacrifice (Dumond, 2000). Customer value can also be viewed as customer desired value and customer perceived value, where the desired value is what the customer wants to receive and the perceived value what has happened (Flint et al., 1997). Customer value can also be split into perceived value and exchange value, where the exchange value is the amount the customer is prepared to pay for the service (Ramsay, 2005). Supplier value is seen as the benefit the supplier 
receives from acting with the customer, for example profit (Purchase et al., 2009; Ramsay and Wagner, 2009). The marketing literature focuses mainly on the customer, and supplier value is hence studied notably less than customer value (e.g. Purchase et al., 2009; Ramsay and Wagner, 2009). In addition, relationship value has been studied because value is created more and more in collaborative relationships (Smals and Smits, 2012; Ulaga, 2003). For a customer and service provider, the creation of value can be considered as essential when engaging in a collaborative relationship (Walter et al., 2001). Payne (2006) explains that the value creation process consists of what value the customer receives, what value the service provider receives, and how the value exchange can be successfully managed to maximize the received total value. Value can also be considered to be equal to the sum of all future cash flows discounted to today. For example in maintenance this would mean the future cash flow from asset utilization, cost control, resource allocation and the SHE (safety, health and environment) factors (Jonker and Haarman, 2006). From the point of view of industrial maintenance, there is relatively little literature considering its value or value elements, and this strengthens the need to formulate and assess the value of maintenance services based on customer collaboration (Ojanen et al., 2012; Tynninen et al., 2012).

In this paper we consider industrial maintenance service value to consist of value elements (e.g. price, flexibility and quality) like Ojanen et al. (2012) present, and value is created with the right combination of these elements. When defining and discussing value and finding the value-creating areas, the term value element offers a suitable perspective to value and to presenting the trade-off between the different elements. The total value of maintenance service can be considered to be the sum of the value elements. Figure 1 presents the aim of this paper, which is to verify the most valued elements for the customer and service provider of maintenance services and to solve the value puzzle; how value can be created by profiling the value elements and the intended win-win situation. The value gap in the figure presents the difference of the customer's and service provider's value elements, which has been tested with the non-parametric tests Wilcoxon and Mann-Whitney U. The value gap is closed with the value element profile that provides a base for value discussions in negotiation situations. In addition to value creation, the win-win situation is highlighted because it is essential that both parties gain benefits from the provided maintenance service. In order to improve the competiveness of the relationship, organizations need to understand what elements create value in maintenance service collaboration (Lapierre, 2000).

Figure 1. Value creation in maintenance services with the help of value elements

Many companies have outsourced their maintenance services wholly or partially, and this underlines the need to evaluate the value of maintenance services and contracts to avoid disagreement and inadequate performance (Kumar et al., 2006; Tynninen et al., 2012). The value discussion is important also from the service provider's point, so that the provider is able to price the services correctly and develop trust between the parties based on common understanding of the value creating elements (Ojanen et al., 2012). With the value element approach we offer one way to find out how the value of industrial maintenance services is modelled and created for each partner. The specific objective of this paper is: to verify the most important value elements of industrial maintenance from the service customer's and service provider's perspective, and to find out the differences between the parties.

The paper is structured as follows. First the theory and the hypotheses are described. Then the research methodology is described in detail. Next the achieved results are shown and discussed. Finally, a summary of the paper and conclusions with future research objectives are presented. 
Author

\section{Theory and hypotheses}

There is not much literature considering the value and value elements of industrial maintenance services. Value has been considered more in b-to-c businesses, and the focus in the value literature concerning services has been on the customer side (Purchase et al., 2009; Ramsay and Wagner, 2009). When articles related to the value elements of services were reviewed, 14 articles considering the customer view and only 4 articles considering the supplier view were found (Tynninen et al., 2012). None of the reviewed articles considered the value elements of industrial maintenance services. Komonen et al. (2007) have not studied value or the total value of a maintenance network directly, as their research concerns especially customer and supplier satisfaction in industrial maintenance, and how customer and job satisfaction are related to each other. But their research supports the fact that maintenance service value can be considered as summed elements, as they also recognize different dimensions and groups of maintenance operations that are included in customer and job satisfaction (e.g. quality of operations, professional skills, cost level and orderliness).

To get a starting point for the possible value elements of industrial maintenance, Tynninen et al. (2012) gathered the value elements suitable for industrial maintenance services from the reviewed service literature. Then the recognized elements were discussed and modified in a workshop of company representatives as Sinkkonen et al. (2013) describe. The idea was to test if the value elements of the literature research were even close to the ones the operators consider as value elements of industrial maintenance service.

\subsection{Industrial maintenance service customer's value elements}

Price, technical quality, dependability, contracts, relationship, reliability, flexibility, reputation of the service provider, accessibility, asset management factors, total solutions, and sustainability were chosen as the industrial maintenance service customer's value elements. Sinkkonen et al. (2013) presented safety at work and environmental safety as new elements in addition to the preliminary list Tynninen et al. (2012) had made. Adding safety to the list makes sense, because the impact of maintenance work on safety issues comes up repeatedly in maintenance literature (e.g. Gulati, 2009; Järviö et al., 2007; Márquez, 2007). Also the increased amount of outcourcing emphasizes the safety at work -element in procurement situations (EU-OSHA, 2012; Lind et al., 2008).

The value elements of the customer can be reviewed also from a more specific view at the item level, comparing the value elements from the point of a high critical and a low critical item. At the operational level in maintenance planning, item criticality has to be categorized to make sure how the maintained items have to be prioritized and that the right maintenance method is identifyed (Márquez, 2007). The items can be categorized with a criticality matrix where item criticality is presented as depending on the failure freguency of the item and the severity of failure or fault (SFS-EN 13306, 2010). For example a critical pump can be considered as a critical item, and the maintenance should focus on continous condition-based maintenance. Conversely, the maintenance of the company garden can be considered as a low critical item and the maintenance strategy could be weekly predetermined maintenance. These different maintenance methods will also affect the value elements higlighted in each situation. For example with a high critical item, availability could be the most important value element, while for a low critical item it could be price (Tynninen et al. 2012). Also the workshop results suggested that there would be differences in the most important value elements depending on item criticality and occasion (Sinkkonen et al., 2013). Based on the literature it is predicted that the value elements of the customer differ according to the item criticality, and we posit

Hypothesis 1: The customer's value elements differ depending on the item criticality. 


\subsection{Industrial maintenance service provider's value elements}

As the maintenance service provider's value elements Tynninen et al. (2012) suggest price, flexibility, reliability, contracts, relationship, total solutions, operator knowledge, availability, asset management factors, access to market, reputation of customer and R\&D. Sinkkonen et al. (2013) presented as elements also safety at work, service ability and orderliness. To be successful in marketing, service providers need to differentiate their service offerings through people and processes that add value, in other words, choose the right value elements. When the customer is correctly assessed, the maintenance service company can offer customized services to each customer and at the same time increase the revenues of the company (Liang, 2010). The theory also suggests that companies that create superior customer value and regularly introduce innovations in service offerings will gain competitive advantage over their competitors (Guenzi and Troilo, 2007).

Like the value elements of the customer, also the value elements of the service provider can be analyzed from a more specific view when comparing the value elements of core and support services. Grönroos (2000) notes that for managerial reasons, services should be distinguished into three groups: core, facilitating and support services. The core service is the service for which the company is on the market. Facilitating services are the services customers need to use the core service, for example a bank card for an ATM. Support services, on the other hand, are services that are not essential for the company but are used to increase the value of the service or to differentiate the service from competitors' service offerings. However, for this paper we consider core and support services to be a wide enough separation to see possible differences in the value elements of maintenance service providers. In industrial maintenance services a core service could be for example mechanical maintenance, and a support service would be gardening outdoors. According to Sinkkonen et al. (2013), differences between the core and support service elements of the service provider were recognized, but the differences were not as clear as with the item criticality. Based on the theory we suggest

Hypothesis 2: The service provider's value elements differ between core and support service.

\subsection{Differences between industrial maintenance service customer's and service provider's value elements}

For example Smith et al. (2012) emphasize that value should always be considered from both sides, how much value can be derived by a company from its customers and also the derived value to the customers from the company. Value also depends upon the participants' perceptions, and even though the companies may work in a network, each of the customers and suppliers have their own motivations, problems and strategies (Ford and McDowell, 1999). This, in addition to the vague definition of value, results in versitile value element listings. In order to create value and improve the competiveness of the maintenance service relationship, the customer and the service provider need to understand what elements create value for each party (Lapierre, 2000).

As presented above as well as by Sinkkonen et al. (2013), when the item criticality and provided service are discussed, there are some significant differences in the listings when comparing the customer and the service provider. For example the service providers do not list environmental safety or asset management factors as value elements like the customers do. It seems that the value elements are partly similar, partly different between the customer and the service provider, but also depend strongly on the occasion, and therefore we posit as our concluding hypothesis

Hypothesis 3: There are differences (a value gap) between the customer's and the service provider's preferred value elements. 


\section{Research methodology}

Because no previous research was found considering the value elements of industrial maintenance services, the survey method was chosen to verify the preliminary elements found by Tynninen et al. (2012) and possibly identify new value elements. The final elements used in the survey were chosen on the basis of the preliminary studies of Tynninen et al. (2012) and Sinkkonen et al. (2013) (Appendix A). The identification and verification of the most important value elements for the customer and service provider in industrial maintenance services and their differences are the primary objective of this study, and are part of a wider research project MaiSeMa (Industrial Maintenance Services in a Renewing Business Network: Identify, Model and Manage Value).

\subsection{Sample}

In Finland, outsourcing has increased the demand for industrial maintenance services, and nowadays maintenance is a significant industry (Hatinen et al., 2012). Due to the developed and organized maintenance industry, Finland is a good testing ground for value element research. An online-survey link was sent to 345 Finnish industrial maintenance professionals. The primary source for the contacts was the Finnish Maintenance Society Promaint, which is an important nationwide actor and has a diverse network of corporations in the maintenance field. The survey was conducted between January-March 2013, and the contact persons received two reminders after the first message. 83 completed questionnaires were received, representing a response rate of $24 \%$. 32 responses were received from maintenance customers and 51 from maintenance service providers.

The most common position $(56 \%)$ of the respondent was working in middle management, for example as a maintenance manager, $21 \%$ of the respondents represented top management, and the rest $(23 \%)$ represented mainly consultants and supervisors. In the responder group, 39\% represented large companies (over 250 workers), and thus the majority represented small or middle sized companies. The customer side represented mainly the industrial goods and services industry (69\%), but also the electricity, gas and heating industry (15\%). None of the customers executed the maintenance services wholly by themselves. The service providers represented mainly mechanical maintenance $(58 \%)$ and electricity (33\%), or a combination of different maintenance types.

\subsection{Survey instrument}

Because value can be interpreted in many ways, in the survey instrument the 16 tested value elements were decided to represent two propositions each (shown in Appendix A). The customer and service provider were thus asked to value 32 propositions on a five-point Likert scale with end points of " strongly disagree" $(=1)$ to "strongly agree" (=5). The customers responded first considering a high critical item to be maintained and after that the same claims were presented for a low critical item to be maintained. To be able to compare the differences of the customer and the service provider it was decided to present the same value elements and claims for both sides in the questionnaire, and so the service provider responded to the same propositions but considering a core service and support service it provided to the customers. It was emphasized to the service provider to respond from their own point of view, not the customer's. The survey instrument was pre-tested by a panel of experts which consisted of company representatives participating in the MaiSeMa-research project.

\subsection{Data analysis}

The data in the survey sample was not normally distributed, and therefore the non-parametric tests Mann-Whitney U and Wilcoxon were used to examine the statistically significant differences in the 
value elements (Devore and Berk, 2012). The reliability of the sum variables was tested by computing the Cronbach's alpha. The values were mainly above the recommended 0.700 or close to it, which indicates that the sum variables were reliable and could be used for further analysis with some regard (Cortina, 1993).

\section{Results and discussion}

\subsection{Results regarding the customer's value elements}

Descriptive statistics and the results of the Wilcoxon test between the high critical and low critical items can be seen in table 1 . For the critical items the customers ranked as the most important value elements reliability, safety at work, environmental safety, operator knowledge, price, and technical quality, which all had means above 4.2. The lowest scores with means below 3.0 were given to $\mathrm{R} \& \mathrm{D}$, access to markets and asset management factors. When considering the low critical items to be maintained, the customers valued most environmental safety, safety at work, operator knowledge, reliability, and price. The value elements with the lowest means were asset management factors, $R \& D$ and access to markets. In addition to the presented propositions, the customers suggested the rapidity of the maintenance service as a factor they value (open-ended question).

\section{Table 1. Value elements depending on item criticality $(\mathrm{HCI}=$ High critical item, $\mathrm{LCI}=\mathrm{Low}$ critical item)}

As can be seen in the table, when comparing the high and low critical items, the survey results support the idea that there are differences between the value elements. It is interesting to see that with the high critical items, reliability is valued even higher than safety at work. Overall safety is valued very high, though, and it seems that companies value the safety risk assessment methods that also Lind et al. (2008) emphasize. For the high critical items, the value elements have substantially higher means. This is understandable because a high critical item is something that can stop the whole production, so the maintenance strategy is overall valued more for a high critical item than for a low critical item (Järviö et al., 2007; Márquez, 2007).

Statistically significant differences $(\mathrm{p}<0.05)$ between the value elements based on the Wilcoxon test can be seen in availability, technical quality, flexibility, reliability, orderliness, R\&D, and access to markets. Of all the statistically differentiating value elements, the customers valued higher the element of the high critical maintenance items than of the low critical items. This confirms the assumption that item criticality affects the importance and prioritizing of maintenance strategy (Márquez, 2007). Because Hypothesis 1 is supported in almost half of the value elements and there are recognizable differences in what the customers value within a high critical item versus a low critical item, it can be stated that the value elements differ depending on item criticality, and this should be considered when profiling the value elements. It is also important that the service provider sees the difference to make the right offering for each item to be maintained and be successful, as Liang (2010) suggests.

The correlation matrix for the high and low critical items can be seen in appendix B. There are a lot of strong correlations of even 0.700 and above. This suggests that the elements are strongly related, and in future research factor analysis would be beneficial to see if some or even all value elements could be merged into bigger groups and complexes. 
Author

\subsection{Results regarding the service provider's value elements}

The descriptive statistics and the results of Hypothesis 2 testing done by Wilcoxon relating the value elements of core and support services are presented in table 2 . The service providers rated the highest in core services operator knowledge, reliability, safety at work, technical quality, environmental safety, and price, which all had mean values 4.40 or higher. The service providers valued least in core services flexibility, access to markets, $R \& D$, and asset management factors. They all had means above 3.30, so still quite high. When looking at the support services, the providers rated highest safety at work, reliability, operator knowledge, environmental safety, and technical quality. The least valued elements were flexibility, access to markets and asset management factors. In addition to the presented propositions, the service providers mentioned perseverance and domestic content as factors they value in maintenance services (open-ended question).

\section{Table 2. Value elements depending on provided service $(\mathrm{CS}=$ Core service, $\mathrm{SS}=$ Support service)}

Based on the theory, we predicted that the core and support services would differ, and overall there were differences in the ranking of value elements between the core and support services, but they were minor and the most important and least valued elements were almost identical. That there were only minor differences was also supported by the Wilcoxon test. The only statistical significant difference $(\mathrm{p}<0.05)$ was in operator knowledge. A potential reason comes up when looking at the survey respondents' open-ended responses. Only a few of the respondents had differentiated the core and support services from each other. It seems that the clear definition in theory had not yet reached the practice.

The correlation matrix for the core and support services can be seen in appendix B. Within the core service there are not nearly as much strong correlations as within the support service, but it can still be seen that the value elements are related to each other. As with the customer's value elements also here factor analysis would be beneficial for identifying more complex value elements.

\subsection{Results regarding the differences between the customer's and service provider's value elements}

The identification of the differences between the maintenance service customer's and service provider's value elements was executed by comparing how the preferred value elements differed when the service provider would wish to maintain the customer's high and low critical items with its core service. Comparison of the provider's support service and customer's preferred value elements was left out because there were no statistically significant differences between the service provider's core and support services, and also the respondents' separation between the services was questionable, because many of the respondents named the same service as core and support one. Table 3 shows the Mann-Whitney U test scores and the test results concerning hypothesis 3 .

Hypothesis 3 is supported $(\mathrm{p}<0.05)$ when comparing the customer's critical items and service provider's core services in operator knowledge, relationship, total solutions, $R \& D$, access to markets, and asset management factors. When the customer's low criticality items and service provider's value elements are compared, there are in addition statistically significant differences $(\mathrm{p}<0.05)$ in availability, technical quality and reliability. There are statistically significant differences especially when considering the customer's low criticality items and the service provider's core services. Compared to the customer, the service provider values the different value elements substantially higher. The service providers did not value any elements under 3.30, and for 
example one of the least valued elements, asset management factors, was still valued notably higher than at the customers' side (3.35 versus 2.54 ).

Table 3. Value element differences between the customer and the service provider

The biggest value gaps seem to be in the least valued elements $\mathrm{R} \& \mathrm{D}$, access to markets and asset management factors, and the difference is also supported statistically. The low valuation of $R \& D$ was expected at least from the customer side, because R\&D in industrial services has many contract-related issues and cooperation is considered complicated (Panesar and Markeset, 2008). In the service providers' side this was slightly surprising, because Sinkkonen et al. (2013) discussed it to be one of the most important value elements in support services. To be able to gain competitive advance it would be important for the customer and service provider to work on this value gap and identify innovation activities that would create value for both parties (Guenzi and Troilo, 2007).

The low score of asset management is also interesting, because asset management has been emphasized in current research and it has been shown that with asset management the customers and service providers can affect the company's operation and capital greatly (Kärri, 2007; Ojanen et al., 2012). The service providers seemed to have recognized this slightly better than the customers, at least they valued it with a notably higher score. The low level of top manager respondents probably had some influence on the score because normally top managers have a broader view of total asset management within the company than middle managers.

\subsection{Value element profile}

There were a lot of strong correlations (above 0.700 , see appendix B) within the value elements at all levels and all the suggested value elements got quite high valuations. This supports the view that the presented value elements can be considered at some levels as industrial maintenance service value elements, and that the value of maintenance services would consist of a value element package. It can also be seen that there are differences between the value elements of the customer and the service provider not only in ranks but also statistically. Especially in b-to-b relations the differences show more clearly because the deviations are not evened out as in this kind of a survey sample. Like Tynninen et al. (2012) suggest, there is a need for a value element profile that the service provider and the customer can use to recognize differences in their value elements while making contracts and measuring the service, and most importantly, discussing issues that create value for each party. With the value element profile there is a base for discussions and suggestions for adequate measures that can be used. The identification of the right value elements for each situation is made more concrete for managers. Also the expected benefits and value can be made clear in the total offer for the customer (Payne, 2006). The service provider would work as a cocreator of value and offer solutions instead of just a service, like Grönroos (2008) emphasizes. For example if the service provider rates operator knowledge as the most important value element and the customer places it as the fourth element, there are three elements that the customer values higher than the service provider. When the service provider is aware of this difference, they can pay attention to this and provide the best combination of value elements, and make a better offer.

Figure 2. Draft of the value element profile for identifying the right value elements and the "value gap" 
In practice the customer and service provider would go through the different value elements in different situations and rank the values according to their importance for them. Then the responses would be reviewed and the most differing elements chosen and put into a radar diagram (figure 2, the chosen elements in figure 2 are based on the survey results, and the elements with statistically significant differences between the customer and service provider were chosen into the diagram). Then the maintenance service customer and service provider would recognize where the biggest gaps are, and they could negotiate about these key differences more specifically before making the final contract, and also consider this in the overall decision making, for example pricing related to improved safety or possible R\&D cooperation in exchange for better technical quality. In the best scenarios this would result in a situation where both parties would gain more value of the contract than originally expected. The organizations would understand what elements create value in the maintenance service collaboration (Lapierre, 2000), and this would result in a win-win situation where the overall value of the relationship would grow and also the competitiveness of the relationship would improve. It should not be forgot, however, that contract-related issues are complicated and require openness and mutual trust (Panesar and Markeset, 2008; Rekola and Haapio, 2009).

\section{Conclusions and suggestions for future research}

The objective of this paper was to verify the most important value elements from the customer's and service provider's perspective, and to find the differences between the parties of industrial maintenance services as well. Overall, all the suggested value elements got quite high valuations with means between 3.0 and even 4.60 (not agreeing nor disagreeing to strongly agreeing), so they can be considered to be elements that at least somehow affect the experienced value of maintenance services. It also shows that value is constituted of different elements. On the basis of the survey results, there are clearly maintenance service value elements that arise above others in all categories, namely reliability, safety at work, environmental safety, and operator knowledge. Also technical quality and price were rated high. Fastness, perseverance and domestic content of the maintenance service were suggested as new factors that would also affect the experienced value. On the other hand, there were also value elements that were constantly rated as less important value elements in all categories. These were access to markets, asset management factors and R\&D. Especially the low valuation of asset management factors was surprising, because there has been a lot of discussion and research regarding the importance of asset management factors, but it seems that the customers and service provides have not yet understood their profit potential. Overall, comprehensive value elements like total solutions, asset management factors, access to markets, and $R \& D$ were rated lower, and this is understandable due to their complex nature. The possible win-win potential and development of these elements should be emphasized. The survey results suggested also that there are differences between the value elements of the customer and the service provider, and also different situations affect the value elements preferred. The statistically significant differences were not as great as expected on the basis of theory, but because there were at least some statistical differences in a big population like this, in business-to-business relations the differences are probably even greater because the means are not evened out.

The paper contributes to the theoretical value discussion of industrial maintenance services and provides value elements that can be considered as the value elements of industrial maintenance services. Until now there has been a lack of knowledge about the specific value elements concerning the industrial maintenance service customer and service provider. The paper also points out that there are differences in maintenance service value elements that should be considered in negotiations. The paper also provides a first draft of a value element profile, which could be used in negotiation situations. Now the profile is rather theoretical because the value elements were verified for the first time and they are also strongly situational. In the future the value element profile will provide also a practical side by offering a negotiation method for assessing and 
discussing value and making it more concrete for the customer and the service provider by visualizing a possible gap in the value elements of the customer and the service provider. Also performance measurement can be value-based, and therefore the value discussion also helps in finding the correct performance measures used in the contract. By successfully closing the gap, the customer and the service provider can reach their maximum value creation potential, and an overall win-win situation in the cooperation can be reached. Of course profiling and discussing the value elements would require openness and interest in honest cooperation.

There are also limitations in the study that should be taken into account in future research. The propositions behind the value elements are compromises that are situation-specific and servicerelated, and there are probably as many views behind the responses as there are respondents. Also it is a weakness of a survey method like this that unconscious preferences cannot be known because the responses are not based on clear measurable values. However, the research did not aim at absolute value, the aim was to add and verify the theoretical knowledge related to the value elements of maintenance services that can be used for discussional purposes (e.g. the value element profile, the function of which is situation-specific and the theory only constructs a starting point for the use).The mean values and sum variables had a high weight in this paper to get an overall view of the situations, but for future research also the value elements should be reviewed in closer detail because in some cases Cronbach's alpha was considerably low. Possible dividing and regrouping of elements should be considered. In the future also the list of elements should be modified and updated. Correlations received little attention because the focus was on finding differences. But because there was a great amount of significant correlations, it would be interesting to test the correlations further and also make a factor analysis to see whether some value elements could be merged.

A major future research target is the building and focusing of the maintenance service value analyser based on the value element profile. The analyser should be studied in different situations, like preventive and corrective maintenance, and also specified for different customers, for example according to size or maintenance service area. Later the analyser could be added with weights to the life-cycle model developed by Sinkkonen et al. (2013) and also included in service offering discussions and presented as a comprehensive manager tool.

\section{References}

Cortina, J. M. (1993) 'What is coefficient alpha? An examination of theory and applications', Journal of Applied Psychology, Vol. 78, No. 1, pp. 98-104.

Devore, J. L. and Berk, K. N. (2012) Modern Mathematical Statistics with Applications, 2nd edition, New York, NY: Springer New York.

Dumond, E. (2000) 'Value management: an underlying framework', International Journal of Operations \& Production Management, Vol. 20, No. 9, pp. 1062-1077.

EU-OHS (2012) 'Procurement of maintenance services and health and safety at work', E-fact 63, Available at: https://osha.europa.eu/en/publications/e-facts/e-fact-63-procurement-of-maintenanceservices-and-health-and-safety-at-work, accessed 27.6.2013.

Flint, D., Woodruff, R. and Gardial, S. (1997) 'Customer value change in industrial marketing relationships: A call for new Strategies and research', Industrial Marketing Management, Vol. 26, No. 2, pp. 163-175. 


\section{Author}

Ford, D. and McDowell, R. (1999) 'Managing business relationships by analyzing the effects and value of different actions', Industrial Marketing Management, Vol. 28, No. 5, pp. 429-442.

Guenzi, P. and Troilo, G. (2007) 'The joint contribution of marketing and sales to the creation of superior customer value', Journal of Business Research, Vol. 60, No. 2, pp. 98-107.

Gulati, R. (2009) Maintenance and reliability best practices: with contributions by Ricky Smith, New York: Industrial Press.

Grönroos, C. (2000) Service management and marketing: a customer relationship management approach, Chichester: Wiley.

Grönroos, C. (2008) 'Service logic revisited: Who creates value? And who co-creates?'; European Business Review, Vol. 20, No. 4, pp. 298-314.

Hatinen, L., Pirttilä, M., Viskari, S. and Kärri, T. (2012) 'The investment logics of Finnish industrial maintenance service providers', International Journal of Strategic Engineering Asset Management, Vol. 1, No. 1, pp. 33-48.

Jonker, R. and Haarman, M. (2006) 'Value Driven Maintenance: What is the actual added value of maintenance?', Uptime Magazine, Nov. 06, Available at: http://www.reliabilityweb.com/art07/value_driven_maintenance_uptime.pdf, accessed 13.5.2013.

Järviö, J., Piispa, T., Parantainen, T. and Åström, T. (2007) Maintenance, Helsinki: KP-Media. (In Finnish)

Komonen, K., Suominen, S. and Kupi, E. (2007) 'Interaction between customer satisfaction, server satisfaction and effectiveness within industrial maintenance, Conference proceedings, The 2nd World Congress on Engineering asset Management, June, 11-14, 2007, Harrogate, UK.

Kumar, R., Markeset, T. and Kumar, U. (2006) 'Implementation and execution of industrial service strategy. A case study from the oil and gas industry', Journal of Quality in Maintenance Engineering, Vol. 12, No. 2, pp. 105-117.

Kärri, T. (2007) Timing of Capacity Change: Models for Capital Intensive Industry, Acta Universitatis Lappeenrantaensis 287, Dissertation, Lappeenranta University of Technology, Finland.

Lapierre, J. (2000) 'Customer-perceived value in industrial contexts', Journal of Business \& Industrial Marketing, Vol. 15, No. 2, pp. 122-145.

Levery, M. (1998) 'Outsourcing maintenance - a question of strategy', Engineering Management Journal, Vol. 8, No. 1, pp. 34-40.

Liang, Y. (2010) 'Integration of data mining technologies to analyze customer value for the automotive maintenance industry', Expert Systems with Applications, Vol. 37, No. 12, pp. 74897496.

Lind, S., Nenonen, S. and Kivistö-Rahnasto, J. (2008) 'Safety risk assessment in industrial maintenance' Journal of Quality in Maintenance Engineering, Vol. 14, No. 2, pp. 205-217.

Márquez, A. C. (2007) The maintenance management framework: Models and methods for complex systems maintenance. - Springer series in reliability engineering, London: SpringerVerlag. 
Ojanen, V., Hatinen, L., Kärri, T, Kässi, T. and Tuominen, M. (2012), 'Flexible investment planning and collaborative maintenance management' in: van der Lei, T., Herder, P. and Wijnia, Y. (Eds.). Asset Management: The State of Art in Europe from a Life Cycle Perspective, Dordrecht, Springer, pp. 65-77.

Panesar, S.S. and Markeset, T. (2008) 'Industrial service innovation through improved contractual relationship', Journal of Quality in Maintenance Engineering, Vol. 14, No. 3, pp. 290-305.

Payne, A. (2006) Handbook of CRM: Achieving excellence in customer management, Oxford: Elsevier, 438 p.

Purchase, S., Goh, T. and Dooley, K. (2009) 'Supplier perceived value: Differences between business-to-business and business-to-government relationships', Journal of Purchasing \& Supply Management, Vol. 15, No. 1, pp. 3-11.

Ramsay, J. (2005) 'The real meaning of value in trading relationships', International Journal of Operations \& Production Management, Vol. 25, No. 5, pp. 549-565.

Ramsay, J. and Wagner, B. (2009) 'Organisational supplying behavior: Understanding supplier needs, wants and preferences', Journal of Purchasing \& Supply Management, Vol. 15, No. 2, pp. 127-138.

Rekola, K. and Haapio, H. (2009) Industrial Services and Service Contracts: A Proactive Approach, Helsinki: The Federation of Finnish Technology Industries.

SFS-EN Std. 13306. (2010) Maintenance, Maintenance terminology, Finnish Standard Association SFS, $53 \mathrm{p}$.

Sinkkonen, T., Kivimäki, H., Marttonen, S. and Kärri, T. (2013) 'A value-based life-cycle framework for networks of industrial maintenance services', The 26th International Congress of Condition Monitoring and Diagnostic Engineering Management, June 11-13, 2013, Helsinki, Finland.

Smals, R. and Smits, A. (2012) 'Value for value-The dynamics of supplier value in collaborative new product development', Industrial Marketing Management, Vol. 41, No. 1, pp. 156-165.

Smith, L., Ng, I. and Maull, R. (2012) 'The three value proposition cycles of equipment-based service', Production Planning \& Control: The Management of Operations, Vol. 23, No. 7, pp. 553570

Tynninen, L., Sinkkonen, T., Marttonen, S. and Ojanen, V. (2012) 'Framework for the value elements of maintenance services', The $2^{\text {nd }}$ International congress on Maintenance Performance Measurement \& Management, September 12-13, 2012, Sunderland, UK.

Ulaga, W. (2003) 'Capturing value creation in business relationships: A customer perspective', Industrial Marketing Management, Vol. 32, No. 8, pp. 677-693.

Walter, A., Ritter, T. and Gemunden, H.G. (2001) 'Value creation in buyer-seller relationships: Theoretical considerations and empirical results from a supplier's perspective', Industrial Marketing Management, Vol. 30, No. 4, pp. 365-377.

Zeithaml, V. (1988) 'Consumer perceptions of price, quality, and value: A means-end model and synthesis of evidence', Journal of Marketing, Vol. 52, No. 3, pp. 2-22. 


\section{Author}

\section{Appendix A}

Appendix A shows the proposed value elements and defining propositions based on the previous literature research of Tynninen et al. (2012) and the workshop results of Sinkkonen et al. (2013).

Availability:

1. The target of the maintenance work functions as expected, its maintainability and repair is easy.

2. The users look after their part of the in use maintenance operations and enhance the maintainability of the item.

Safety at work:

3. The operational conditions and safety increase along the service.

4. The maintenance is performed according to safety policies.

Environmental safety:

5. The maintenance service performer recognizes the environmental safety hazards.

6 . The maintenance is performed according to environmental safety policies.

Technical quality:

7. The maintenance service outcome is as expected.

8 . The maintenance service outcome is sustained for the promised time.

Flexibility:

9. The maintenance service partner bends from its claims (e.g. . delivery time)

10. The maintenance services are tailored based on need.

Reliability:

11. The maintenance service cooperation is executed on time and as promised

12. The maintenance service cooperation is based on confidentiality.

Operator knowledge:

13. The maintenance service provider has the knowledge to solve upcoming problems.

14. The maintenance service operators are professionally skilled and qualified.

Orderliness:

15. The resources and timetable of the maintenance service can be planned well in advance.

16. The maintenance service operations are developed in cooperation.

Reputation:

17. The current reputation of the maintenance service partner is good.

18. The previous experiences with the maintenance service partner have been positive.

Relationship:

19. The maintenance service cooperation works well considering the conditions of all partners.

20. The information exchange works between the maintenance service partners.

Contracts:

21. The maintenance service warranty and terms of payment are kept and executed as promised.

22. The risks and responsibilities considering the maintenance services are shared between the customer and the service provider.

Total solutions:

23. The maintenance service cooperation covers comprehensively the whole maintenance services (from management to execution)

24. The maintenance service covers the whole life span of the item.

$R \& D$ :

25. Own research and development can be developed with the maintenance service partner.

26. The maintenance service partner can provide information and knowledge related to the development of R\&D activities.

Price:

27. The price paid for the maintenance service corresponds with the received service.

28 . The price is negotiated in cooperation with the maintenance service partner.

Access to markets:

29. The maintenance service cooperation enables contact with new customers.

30. The maintenance service cooperation enables starting a new type of business

Asset management factors:

31. The maintenance service partner is responsible for the spare part storage so that it does not tie your own resources and capital.

32. The maintenance service partner owns the fixed assets, for example the maintained items so that they do not stress your own balance sheet. 


\section{Appendix B}

Appendix B shows the correlation coefficients between the value elements.

\begin{tabular}{|c|c|c|c|c|c|c|c|c|c|c|c|c|c|c|c|}
\hline $\begin{array}{c}\text { Value element (high } \\
\text { critical item) }\end{array}$ & 1 & 2 & 3 & 4 & 5 & 6 & 7 & 8 & 9 & 10 & 11 & 12 & 13 & 14 & 15 \\
\hline 1 Availability & & & & & & & & & & & & & & & \\
\hline 2 Safety at work &, 571 & & & & & & & & & & & & & & \\
\hline 3 Environmental safety &, 500 &, 577 & & & & & & & & & & & & & \\
\hline 4 Technical quality & 806 & ,635 &, 574 & & & & & & & & & & & & \\
\hline 5 Flexibility & ,116 &, 236 &, 379 & ,268 & & & & & & & & & & & \\
\hline 6 Reliability &, 228 &, 305 &, 352 &, 454 & 376 & & & & & & & & & & \\
\hline 7 Operator knowledge & 688 &, 542 &, 367 & 687 &, 386 &, 553 & & & & & & & & & \\
\hline 8 Orderliness & ,656 &, 539 &, 550 & 699 &, 318 &, 526 & ,673 & & & & & & & & \\
\hline 9 Reputation & 412 & 486 & 696 &, 446 & 644 & 466 &, 545 & 496 & & & & & & & \\
\hline 10 Relationship & 609 & 600 & 491 & ,708 &, 596 & ,623 & 843 & 645 & 694 & & & & & & \\
\hline 11 Contracts & ,327 &, 389 & 469 & 367 & 441 & 497 &, 591 & 401 & 699 & ,632 & & & & & \\
\hline 12 Total solutions &, 064 & , 142 &, 263 & ,166 & ,162 & ,197 & 189 &, 312 &, 380 & ,160 &, 286 & & & & \\
\hline $13 \mathrm{R} \& D$ &, 193 &, 191 &, 572 &, 172 &, 315 &, 318 &, 171 & 457 &, 567 &, 326 & 462 & 478 & & & \\
\hline 14 Price & ,669 & 619 &, 712 &, 767 &, 312 & 421 & 636 &, 730 &, 546 &, 536 & 397 &, 246 &, 325 & & \\
\hline 15 Access to markets & 219 &, 229 &, 156 & , 190 &, 040 & ,086 & ,208 &, 020 &, 152 &, 039 &, 069 & 090 & 469 & $\begin{array}{c}13 \\
5\end{array}$ & \\
\hline $\begin{array}{l}16 \text { Asset management } \\
\text { factors }\end{array}$ & 400 &, 371 &, 363 &, 514 &, 141 & ,194 & 400 & ,265 &, 312 &, 556 &, 275 & ,186 &, 328 & $\begin{array}{c}.32 \\
6 \\
\end{array}$ & $\begin{array}{r}.26 \\
9 \\
\end{array}$ \\
\hline \multicolumn{16}{|c|}{$\begin{array}{l}\text { ***. Correlation is significant at the } 0.01 \text { level } \\
\text { (2-tailed). } \\
\text { *. Correlation is significant at the } 0.05 \text { level ( } 2 \text { - } \\
\text { tailed). }\end{array}$} \\
\hline $\begin{array}{c}\begin{array}{c}\text { Value element (low critical } \\
\text { item) }\end{array} \\
\end{array}$ & 1 & 2 & 3 & 4 & 5 & 6 & 7 & 8 & 9 & 10 & 11 & 12 & 13 & 14 & 15 \\
\hline $\begin{array}{l}1 \text { Availability } \\
2 \text { Safety at work }\end{array}$ & .579 & & & & & & & & & & & & & & \\
\hline 3 Environmental safety &, 437 &, 585 & & & & & & & & & & & & & \\
\hline 4 Technical quality &, 483 & , 499 & 453 & & & & & & & & & & & & \\
\hline 5 Flexibility & 197 & ,170 & 410 & ,135 & & & & & & & & & & & \\
\hline 6 Reliability &, 442 &, 221 & 465 & 458 &, 528 & & & & & & & & & & \\
\hline 7 Operator knowledge &, 507 & ,303 &, 359 & ,762 & 213 & .548 & & & & & & & & & \\
\hline 8 Orderliness &, 344 & 244 & 468 & 456 & 421 &, 791 & ,593 & & & & & & & & \\
\hline 9 Reputation &, 415 &, 322 &, 530 & , 421 & 468 & , 494 &, 408 &, 539 & & & & & & & \\
\hline 10 Relationship &, 524 & 248 & 459 &, 588 &, 439 &, 731 & 676 & ,707 & , 676 & & & & & & \\
\hline 11 Contracts & ,289 &, 310 &, 454 &, 379 & 659 &, 544 & 369 & 457 &, 545 &, 582 & & & & & \\
\hline 12 Total solutions & ,274 & ,270 & ,309 &, 256 & ,163 & ,308 & ,236 & ,111 & 242 &, 303 & 394 & & & & \\
\hline $13 \mathrm{R} \& D$ & , 193 & ,139 & ,284 & - &, 311 &, 347 & - &, 373 &, 223 & ,293 & ,353 & ,003 & & & \\
\hline 14 Price & , 429 & , 458 &, 508 &, 774 & ,084 & 6610 &, 578 &, 424 & , 424 & .579 &, 357 &, 348 & , & & \\
\hline 15 Access to markets &, 160 &, 151 &, 329 &, 224 &, 319 &, 135 & $\begin{array}{c}- \\
, 167\end{array}$ &, 228 &, 250 & ,203 &, 342 & , & 812 &, 114 & \\
\hline 16 Asset management factors & ,165 & ,030 & 139 & ,146 &, 122 & 285 & ,145 & ,131 & 187 & ,229 & ,243 & ,288 &, 358 &, 236 & ,252 \\
\hline
\end{tabular}




\section{Author}

\begin{tabular}{|c|c|c|c|c|c|c|c|c|c|c|c|c|c|c|c|}
\hline Value element (core service) & 1 & 2 & 3 & 4 & 5 & 6 & 7 & 8 & 9 & 10 & 11 & 12 & 13 & 14 & 15 \\
\hline 1 Availability & & & & & & & & & & & & & & & \\
\hline 2 Safety at work &, 589 & & & & & & & & & & & & & & \\
\hline 3 Environmental safety &, 421 & , 44 & & & & & & & & & & & & & \\
\hline 4 Technical quality &, 482 & ,63 & $3^{.57}$ & & & & & & & & & & & & \\
\hline 5 Flexibility &, 337 & $\begin{array}{l}, 27 \\
8\end{array}$ & $\begin{array}{l}, 29 \\
2\end{array}$ & $\begin{array}{l}, 29 \\
7\end{array}$ & & & & & & & & & & & \\
\hline 6 Reliability &, 448 & ,65 & $\begin{array}{l}.62 \\
8^{* 4}\end{array}$ & .58 & 324 & & & & & & & & & & \\
\hline 7 Operator knowledge &, 576 & , 61 & 45 & ,68 &, 426 & $\begin{array}{l}66 \\
8+\end{array}$ & & & & & & & & & \\
\hline 8 Orderliness &, 410 & $\frac{33}{5}$ & $\begin{array}{l}.55 \\
0^{\circ}\end{array}$ & $\frac{47}{5}$ &, 593 & $\frac{43}{2,4}$ & , & & & & & & & & \\
\hline 9 Reputation &, 474 &, 500 & ,39 &., 53 &, 471 & ${ }_{0}^{42}$ & $\begin{array}{l}61 \\
6\end{array}$ & $\frac{70}{4}$ & & & & & & & \\
\hline 10 Relationship &, 322 & $\frac{49}{3}$ & $\frac{43}{9^{-4}}$ & $\frac{61}{1+4}$ &, 442 & , 49 & $\frac{61}{4}$ & $\frac{68}{4}$ & $\begin{array}{l}72 \\
8.4\end{array}$ & & & & & & \\
\hline 11 Contracts & ,286 & $\underset{6}{, 23}$ & $\begin{array}{l}43 \\
5\end{array}$ & $\frac{47}{3}$ & ,602 & $3^{4 *}$ & $\begin{array}{l}, 50 \\
0 .\end{array}$ & $\frac{63}{7^{* \prime}}$ & $\begin{array}{l}.56 \\
11^{*}\end{array}$ & $\frac{62}{4}$ & & & & & \\
\hline 12 Total solutions & ,175 &, 21 & $\frac{36}{6}$ & $\frac{, 33}{3}$ &, 351 & ,29 & $\frac{, 33}{3}$ & $\begin{array}{l}, 47 \\
3\end{array}$ & 30 & $\begin{array}{c}, 24 \\
9\end{array}$ & $\begin{array}{c}, 25 \\
5\end{array}$ & & & & \\
\hline $13 \mathrm{R} \& \mathrm{D}$ & 314 &, 37 &, 13 & $\frac{31}{6}$ &, 478 & $\frac{28}{5}$ &, 38 & $\frac{50}{4}$ & ,50 & $\frac{48}{3^{* *}}$ & $\frac{43}{3}$ & $\frac{34}{4}$ & & & \\
\hline 14 Price &, 362 & $\frac{22}{3}$ & $\frac{29}{8}$ &, 26 & .584 &, 26 & $\frac{49}{7}$ & $\begin{array}{l}.58 \\
8\end{array}$ & $\begin{array}{l}45 \\
5\end{array}$ & $\begin{array}{l}.54 \\
0^{* 4}\end{array}$ & $\frac{61}{1{ }^{*}}$ & $\begin{array}{c}13 \\
5\end{array}$ & $\begin{array}{c}.22 \\
0\end{array}$ & & \\
\hline 15 Access to markets & ,203 &, 17 & $\begin{array}{l}, 20 \\
1\end{array}$ & $\begin{array}{l}, 26 \\
1\end{array}$ &, 343 &, 200 & $\frac{, 35}{1^{+}}$ & $4^{-49}$ & $\frac{50}{2+}$ & $\begin{array}{l}50 \\
8^{*}\end{array}$ & .53 & $\begin{array}{c}, 03 \\
0\end{array}$ &, 44 & $\begin{array}{l}41 \\
7^{-1}\end{array}$ & \\
\hline 16 Asset management factors & .028 & $\frac{11}{21}$ & $\begin{array}{c}, 17 \\
1\end{array}$ & $\begin{array}{c}, 12 \\
9\end{array}$ & 000 & $\begin{array}{c}, 12 \\
8\end{array}$ & $\begin{array}{c}, 09 \\
3\end{array}$ & $\begin{array}{l}, 14 \\
9\end{array}$ & $\begin{array}{l}.25 \\
8\end{array}$ &, 22 & $\begin{array}{l}42 \\
8\end{array}$ & $\begin{array}{l}, 02 \\
8\end{array}$ & $\begin{array}{c}12 \\
5\end{array}$ & $\begin{array}{l}, 16 \\
2\end{array}$ & $\begin{array}{l}, 22 \\
8\end{array}$ \\
\hline \multicolumn{16}{|c|}{$\begin{array}{l}\text { **. Correlation is significant at the } 0.01 \text { level ( } 2- \\
\text { tailed). } \\
\text { *. Correlation is significant at the } 0.05 \text { level }(2- \\
\text { tailed). }\end{array}$} \\
\hline $\begin{array}{c}\begin{array}{c}\text { Value element (support } \\
\text { service) }\end{array} \\
\end{array}$ & 1 & 2 & 3 & 4 & 5 & 6 & 7 & 8 & 9 & 10 & 11 & 12 & 13 & 14 & 15 \\
\hline $\begin{array}{l}1 \text { Availability } \\
2 \text { Safety at work }\end{array}$ & $\begin{array}{l}.57 \\
9 *\end{array}$ & & & & & & & & & & & & & & \\
\hline 3 Environmental safety &, 54 &, 738 & & & & & & & & & & & & & \\
\hline 4 Technical quality & $\frac{, 72}{4}$ & ,706 & $2^{7 *}$ & & & & & & & & & & & & \\
\hline 5 Flexibility & , 45 &, 461 & $\begin{array}{l}36 \\
1\end{array}$ & $\frac{40}{7^{*}}$ & & & & & & & & & & & \\
\hline 6 Reliability & $\frac{52}{1 *}$ & 679 & ,63 & $\frac{67}{4}$ &, 525 & & & & & & & & & & \\
\hline 7 Operator knowledge & $3^{.4}$ &, 566 & , 50 & ,69 &, 442 & ,69 & & & & & & & & & \\
\hline 8 Orderliness & .54 &, 539 &, .52 & $5^{\circ}$ & 495 & $\frac{66}{2^{* *}}$ & $\frac{71}{1}$ & & & & & & & & \\
\hline 9 Reputation & $\begin{array}{l}58 \\
1^{*}\end{array}$ & 670 & $1^{5 *}$ & , 65 &, 504 & $\begin{array}{l}65 \\
5\end{array}$ & $\frac{69}{2+4}$ & $\frac{71}{6}$ & & & & & & & \\
\hline 10 Relationship & $\frac{71}{9+}$ &, 571 & $\frac{57}{2 *}$ & $3^{7}$ &, 370 & 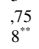 & $\frac{81}{1}$ &, 74 & $7^{, 70}$ & & & & & & \\
\hline 11 Contracts & 51 & ,484 & , 59 & $\frac{62}{4^{* 4}}$ &,., 01 & $\begin{array}{l}56 \\
1^{*}\end{array}$ & $\begin{array}{l}57 \\
8\end{array}$ & $\begin{array}{l}53 \\
8^{404}\end{array}$ & $\begin{array}{l}, 64 \\
8^{* *}\end{array}$ & $\begin{array}{l}61 \\
1^{* *}\end{array}$ & & & & & \\
\hline 12 Total solutions & $\begin{array}{l}36 \\
9^{\circ}\end{array}$ & 446 & $\frac{34}{2}$ & , 49 &, 324 & $\begin{array}{l}, 42 \\
0\end{array}$ & $\begin{array}{l}47 \\
1\end{array}$ & $\begin{array}{l}46 \\
0^{-4}\end{array}$ & $\begin{array}{l}, 72 \\
5^{* *}\end{array}$ & $\frac{43}{7^{* *}}$ & $\frac{47}{4}$ & & & & \\
\hline $13 \mathrm{R} \& \mathrm{D}$ &, 57 & ,485 & , 44 & $\begin{array}{l}64 \\
8 \\
8 *\end{array}$ & 411 & $\begin{array}{l}59 \\
8^{* 4}\end{array}$ & $\begin{array}{l}69 \\
9^{9}\end{array}$ & ,61 & $\frac{72}{2_{2}^{*}}$ & $\frac{81}{2+}$ & $\begin{array}{l}69 \\
6\end{array}$ & $\frac{, 52}{2^{20}}$ & & & \\
\hline 14 Price & , 49 &, 597 & $\frac{62}{7^{* *}}$ &, 59 &, 529 &, 54 & $\begin{array}{l}, 52 \\
1^{* 2}\end{array}$ & $\frac{.51}{5}$ & ,50 & $\begin{array}{l}47 \\
8^{* *}\end{array}$ & $\begin{array}{l}47 \\
2^{2 *}\end{array}$ & $\frac{38}{2}$ & $\begin{array}{l}49 \\
8 \\
8 *\end{array}$ & & \\
\hline 15 Access to markets &, 500 & 409 & $\frac{36}{3}$ & $\begin{array}{l}.58 \\
5^{\circ}\end{array}$ & 246 & $\begin{array}{l}38 \\
1^{\circ}\end{array}$ & $\frac{, 52}{9^{*}}$ & $\begin{array}{l}43 \\
5 \\
5\end{array}$ & , 49 & ,62 & $\begin{array}{l}, 54 \\
5^{-10}\end{array}$ & $\frac{40}{2}$ & $\begin{array}{l}80 \\
5\end{array}$ & $\begin{array}{l}, 56 \\
6 \\
6 *\end{array}$ & \\
\hline 16 Asset management factors & $\begin{array}{c}, 23 \\
6\end{array}$ & .166 & $\begin{array}{c}12 \\
8\end{array}$ & $\frac{31}{5}$ & .054 & , &, 23 & ,08 & $\begin{array}{l}4 \\
, 27 \\
9\end{array}$ &, 17 & , 44 &, 10 &, 15 & $\begin{array}{l}0 \\
, 10\end{array}$ & 162 \\
\hline
\end{tabular}


FIGURES AND TABLES IN TEXT:

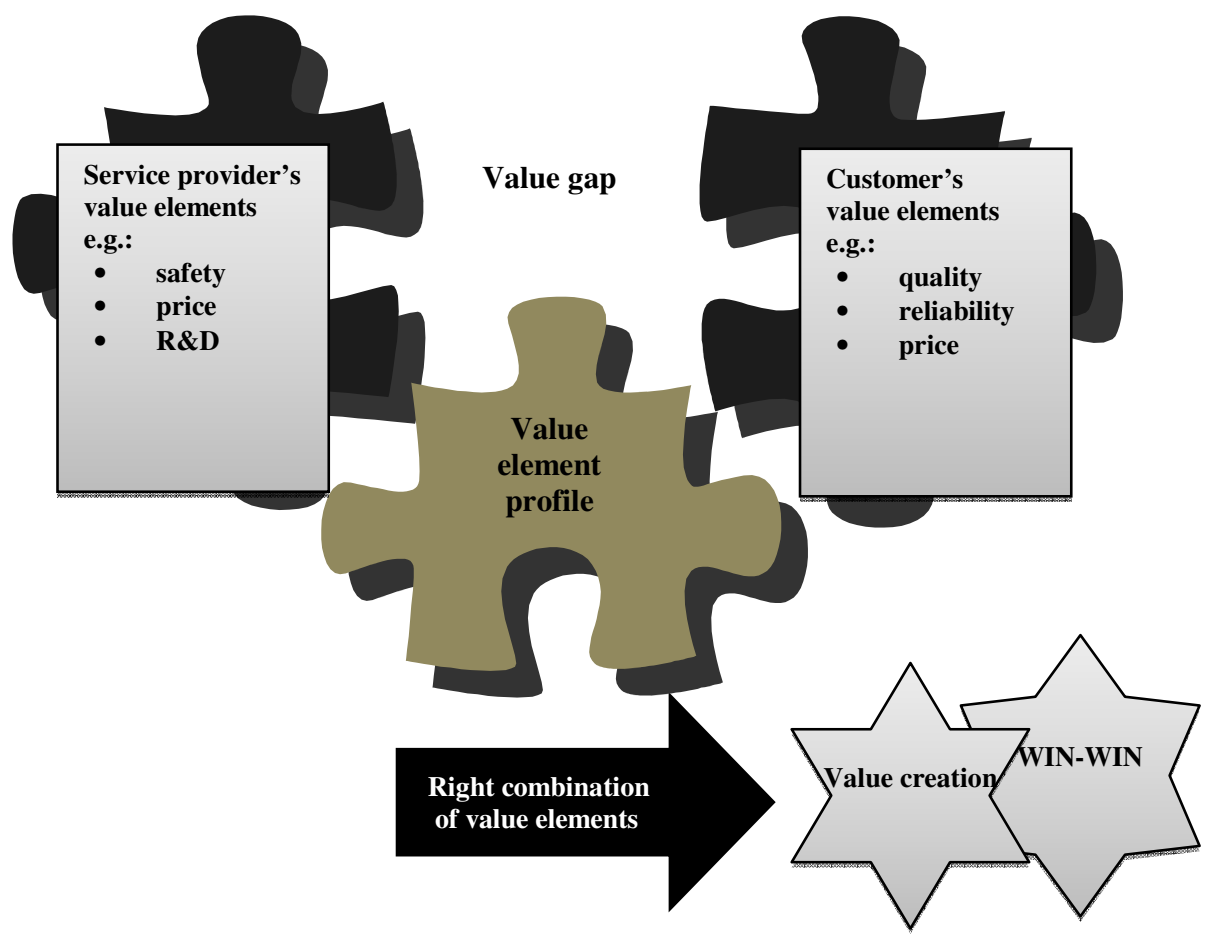

Figure 1. Value creation in maintenance services with the help of value elements 
Author

Table 1. Value elements depending on item criticality $(\mathrm{HCI}=$ High critical item, LCI=Low critical item)

\begin{tabular}{|c|c|c|c|c|c|c|c|c|c|c|}
\hline Value element & $\begin{array}{c}\alpha \\
\mathrm{HCI}\end{array}$ & $\begin{array}{c}\text { Mean } \\
\text { HCI }\end{array}$ & $\begin{array}{l}\text { SD } \\
\mathrm{HCI}\end{array}$ & $\begin{array}{c}\text { Rank } \\
\text { HCI }\end{array}$ & $\stackrel{\alpha}{\mathrm{LCI}}$ & $\begin{array}{l}\text { Mean } \\
\text { LCI }\end{array}$ & $\begin{array}{l}\text { SD } \\
\text { LCI }\end{array}$ & $\begin{array}{l}\text { Rank } \\
\text { LCI }\end{array}$ & $\begin{array}{l}\text { Z } \\
\text { score/sig.level }\end{array}$ & Hypothesis 1 \\
\hline Availability & 0.798 & 4.11 & 1.10 & 9 & 0.455 & 3.76 & 0.80 & 11 & $-2.102 / 0.036^{*}$ & Supported \\
\hline Safety at work & 0.407 & 4.45 & 0.58 & 2 & 0.696 & 4.41 & 0,67 & 2 & $-0.618 / 0.537$ & Not supported \\
\hline $\begin{array}{l}\text { Environmental } \\
\text { safety }\end{array}$ & 0.816 & 4.39 & 0.76 & 3 & 0.819 & 4.45 & 0.64 & 1 & $-0.479 / 0.632$ & Not supported \\
\hline Technical quality & 0.874 & 4.26 & 0.85 & 6 & 0.821 & 4.03 & 0.95 & 7 & $-2.385 / 0.017^{*}$ & Supported \\
\hline Flexibility & 0.563 & 4.09 & 0.67 & 10 & 0.384 & 3.76 & 0.69 & 11 & $-2.226 / 0.026^{*}$ & Supported \\
\hline Reliability & 0.656 & 4.55 & 0.49 & 1 & 0.737 & 4.21 & 0.80 & 4 & $-2.644 / 0.008^{* *}$ & Supported \\
\hline Operator knowledge & 0.830 & 4.31 & 0.67 & 4 & 0.751 & 4.29 & 0.66 & 3 & $-0.534 / 0.593$ & Not supported \\
\hline Orderliness & 0.667 & 4.13 & 0.82 & 8 & 0.890 & 3.77 & 1.17 & 10 & $-2.067 / 0.039^{*}$ & Supported \\
\hline Reputation & 0.596 & 4.18 & 0.54 & 7 & 0.881 & 4.02 & 0.78 & 8 & $-1.907 / 0.057$ & Not supported \\
\hline Relationship & 0.923 & 3.98 & 0.87 & 11 & 0.803 & 4.05 & 0.87 & 6 & $-0.087 / 0.931$ & Not supported \\
\hline Contracts & 0.700 & 3.87 & 0.88 & 12 & 0.545 & 3.84 & 0.80 & 9 & $-0.378 / 0.706$ & Not supported \\
\hline Total solutions & 0.714 & 3.72 & 0.89 & 13 & 0.294 & 3.68 & 0.77 & 13 & $-0.383 / 0.701$ & Not supported \\
\hline$R \& D$ & 0.813 & 3.22 & 1.01 & 14 & 0.959 & 2.50 & 1.01 & 15 & $-3.089 / 0.002^{* *}$ & Supported \\
\hline Price & 0.327 & 4.27 & 0.64 & 5 & 0.682 & 4.20 & 0.77 & 5 & $-0.915 / 0.360$ & Not supported \\
\hline Access to markets & 0.907 & 3.06 & 1.13 & 15 & 0.912 & 2.45 & 1.10 & 16 & 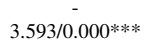 & Supported \\
\hline Asset mgmt. factors & 0.698 & 2.53 & 1.13 & 16 & 0.674 & 2.69 & 1.11 & 14 & $-0.793 / 0.428$ & Not supported \\
\hline
\end{tabular}


Title

Table 2. Value elements depending on provided service $(\mathrm{CS}=$ Core service, $\mathrm{SS}=$ Support service)

\begin{tabular}{|c|c|c|c|c|c|c|c|c|c|c|}
\hline Value element & $\stackrel{\alpha}{\mathrm{CS}}$ & $\begin{array}{l}\text { Mean } \\
\text { CS }\end{array}$ & $\begin{array}{l}\text { SD } \\
\text { CS }\end{array}$ & $\begin{array}{c}\text { Rank } \\
\text { CS }\end{array}$ & $\begin{array}{c}\alpha \\
\text { SS }\end{array}$ & $\begin{array}{l}\text { Mean } \\
\text { SS }\end{array}$ & $\begin{array}{l}\text { SD } \\
\text { SS }\end{array}$ & $\begin{array}{l}\text { Rank } \\
\text { SS }\end{array}$ & $\begin{array}{l}\text { Z } \\
\text { score/sig.level }\end{array}$ & Hypothesis 2 \\
\hline Availability & 0.672 & 4.26 & 0.74 & 9 & 0.639 & 4.32 & 0.62 & 7 & $-1.306 / 0.192$ & Not supported \\
\hline Safety at work & 0.602 & 4.60 & 0.44 & 3 & 0.730 & 4.53 & 0.53 & 1 & $-0.708 / 0.479$ & Not supported \\
\hline $\begin{array}{l}\text { Environmental } \\
\text { safety }\end{array}$ & 0.682 & 4.43 & 0.59 & 5 & 0.877 & 4.48 & 0.61 & 4 & $-0.443 / 0.658$ & Not supported \\
\hline Technical quality & 0.793 & 4.48 & 0.56 & 4 & 0.916 & 4.47 & 0.67 & 5 & $0.000 / 1.000$ & Not supported \\
\hline Flexibility & 0.440 & 3.98 & 0.75 & 13 & 0.676 & 3.98 & 0.75 & 14 & $0.000 / 1.000$ & Not supported \\
\hline Reliability & 0.502 & 4.63 & 0.46 & 2 & 0.555 & 4.52 & 0.51 & 2 & $-1.882 / 0.060$ & Not supported \\
\hline Operator knowledge & 0.678 & 4.65 & 0.47 & 1 & 0.812 & 4.52 & 0.61 & 2 & $-2.072 / 0.038^{*}$ & Supported \\
\hline Orderliness & 0.801 & 4.26 & 0.78 & 9 & 0.791 & 4.20 & 0.72 & 10 & $-0.291 / 0.771$ & Not supported \\
\hline Reputation & 0.628 & 4.28 & 0.57 & 8 & 0.674 & 4.28 & 0.56 & 8 & $-0.759 / 0.448$ & Not supported \\
\hline Relationship & 0.758 & 4.39 & 0.61 & 7 & 0.785 & 4.33 & 0.66 & 6 & $-0.041 / 0.967$ & Not supported \\
\hline Contracts & 0.429 & 4.19 & 0.62 & 11 & 0.382 & 4.05 & 0.71 & 12 & $-1.148 / 0.251$ & Not supported \\
\hline Total solutions & 0.586 & 4.08 & 0.78 & 12 & 0.767 & 4.11 & 0.85 & 11 & $-0.186 / 0.852$ & Not supported \\
\hline$R \& D$ & 0.799 & 3.93 & 0.82 & 15 & 0.865 & 4.00 & 0.87 & 13 & $-0.041 / 0.967$ & Not supported \\
\hline Price & 0.580 & 4.40 & 0.59 & 6 & 0.497 & 4.27 & 0.63 & 9 & $-0.984 / 0.325$ & Not supported \\
\hline Access to markets & 0.812 & 3.94 & 0.85 & 14 & 0.889 & 3.87 & 0.98 & 15 & $-1.040 / 0.298$ & Not supported \\
\hline Asset mgmt. factors & 0.352 & 3.35 & 0.70 & 16 & 0.584 & 3.30 & 0.98 & 16 & $-0.447 / 0.655$ & Not supported \\
\hline
\end{tabular}

2-tailed test $* \mathrm{p}<0.05, * * \mathrm{p}<0.01, * * * \mathrm{p}<0.001, \mathrm{SD}=$ Standard deviation

Table 3. Value element differences between the customer and the service provider

\begin{tabular}{l|cl|cl}
\hline Value element & $\begin{array}{c}\text { Z score/sig.level when } \\
\text { comparing the differences } \\
\text { between the high critical } \\
\text { item and core service }\end{array}$ & Hypothesis 3 & $\begin{array}{c}\text { Z score/sig.level } \\
\text { when comparing the } \\
\text { ifferences between the low } \\
\text { critical item and core service }\end{array}$ & Hypothesis 3 \\
\hline Availability & $-0.295 / 0.768$ & Not supported & $-3.225 / 0.001 * *$ & Supported \\
Safety at work & $-1.000 / 0.317$ & Not supported & $-0.972 / 0.331$ & Not supported \\
Environmental safety & $-0.166 / 0.868$ & Not supported & $-0.972 / 0.331$ & Not supported \\
Technical quality & $-0.871 / 0.384$ & Not supported & $-2.118 / 0.034 *$ & Supported \\
Flexibility & $-0.811 / 0.418$ & Not supported & $-1.390 / 0.165$ & Not supported \\
Reliability & $-0.731 / 0.465$ & Not supported & $-2.442 / 0.015 *$ & Supported \\
Operator knowledge & $-2.539 / 0.011^{*}$ & Supported & $-2.587 / 0.010^{*}$ & Supported \\
Orderliness & $-0.752 / 0.452$ & Not supported & $-1.656 / 0.098$ & Not supported \\
Reputation & $-0-756 / 0.450$ & Not supported & $-1.320 / 0.187$ & Not supported \\
Relationship & $-2.082 / 0.037 *$ & Supported & $-1.645 / 0.100$ & Not supported \\
Contracts & $-1.435 / 0.151$ & Not supported & $-1.878 / 0.060$ & Not supported \\
Total solutions & $-1.903 / 0.057$ & Supported & $-2.250 / 0.024 *$ & Supported \\
R\&D & $-3.090 / 0.002 * *$ & Supported & $-6.743 / 0.000^{* * *}$ & Supported \\
Price & $-0.804 / 0.422$ & Not supported & $-1.037 / 0.300$ & Not supported \\
Access to markets & $-3.544 / 0.000^{* * *}$ & Supported & $-5.251 / 0.000^{* * *}$ & Supported \\
Asset mgmt. factors & $-3.804 / 0.000^{* * *}$ & Supported & $-3.336 / 0.001 * *$ & Supported \\
\hline -tailed test $* \mathrm{p}<0.05 * * * p<0.01 * * * *<0.001$ & &
\end{tabular}


Author

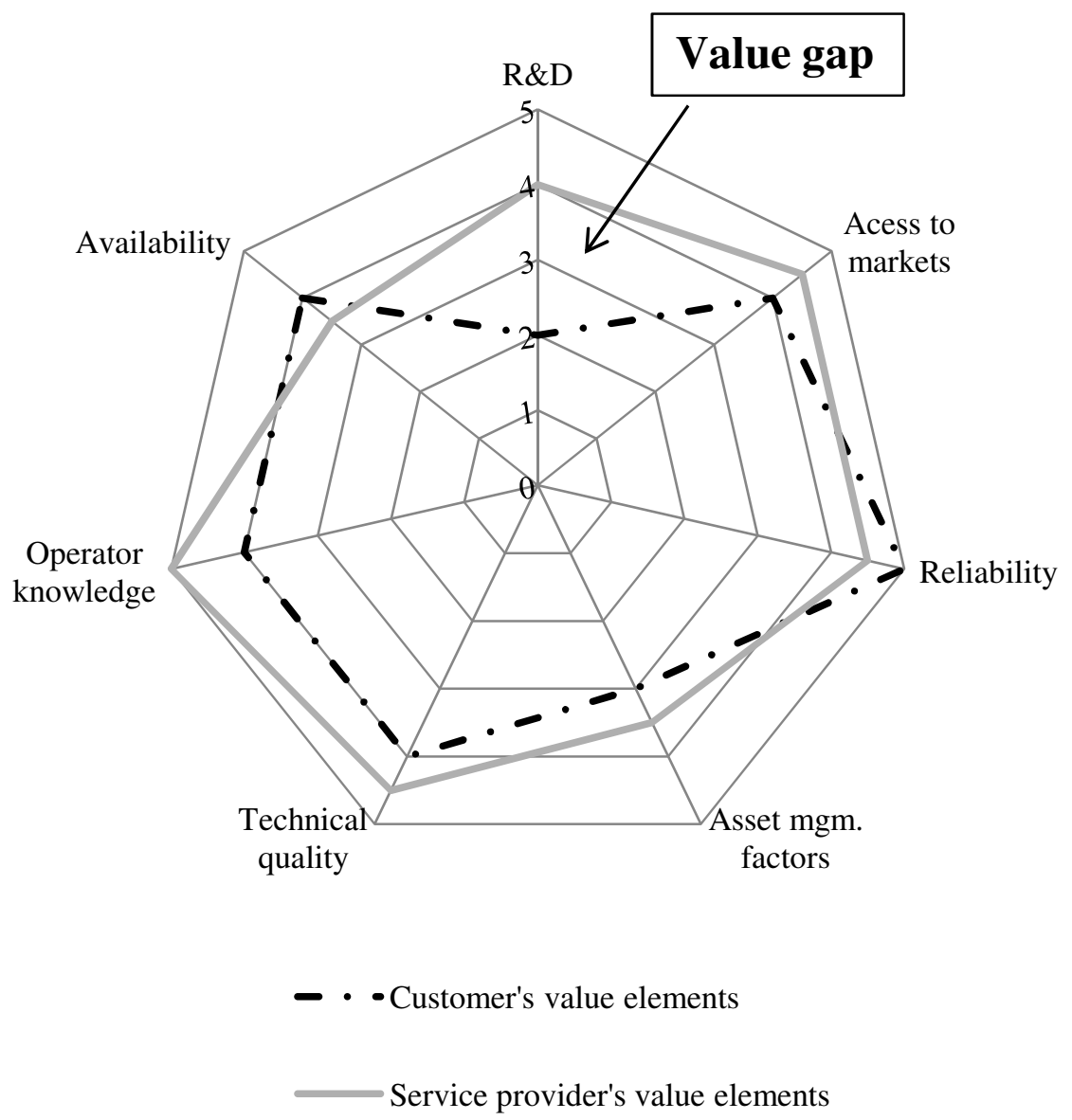

Figure 2. Draft of the value element profile for identifying the right value elements and the "value gap" 